LAERE MIDDEL ODK

\title{
Technology Comprehension in a More-Than-Human World
}

\author{
By Peter Danholt
}

Korrekt citering af denne artikel efter APA-systemet

(American Psychological Association System, 7th Edition):

Danholt, P. (2021). Technology Comprehension in a More-Than-Human World. Learning Tech - Tidsskrift for læremidler, didaktik og teknologi, (10), 169-190. DOI 10.7146/It.v6i10.125722 
Undoubtedly, digital technologies have a substantial impact on our societies. Therefore, it is relevant to introduce the course "technology comprehension" in public school. Equally so, it is important to discuss the content of the course and specifically, how technology is conceived through the stated learning goals. Based on the field of science and technology studies (STS), I analyse the course's implicit technology comprehension and I argue that an understanding of technology as an actor in a more-than-human world needs to be included. This implies emphasizing the complexity, opacity and 'unruly' aspects of technology and thereby empowering the students not to become masters of technology exclusively, but to live in a more-than-human world. The article is concluded by an inconclusive list of suggestions for how to develop the course. The hope is that the list can inspire practitioners in public school to develop their own ideas and learning activities.

Digitale teknologier har utvivlsomt en betydelig indvirkning på vores samfund. Derfor er det relevant at indføre faget "teknologiforståelse" i folkeskolen. Ligeledes er det vigtigt at diskutere kursets indhold, og specifikt hvordan teknologi beskrives og udtrykkes gennem fagets læringsmål. Baseret på feltet videnskab og teknologi (STS) analyserer jeg kursets implicitte teknologiforståelse og argumenterer for, at en forståelse af teknologi som en aktør i en mere-end-menneskelig verden er fraværende og bør inkluderes. Dette indebærer en forståelse af teknologi som kompleks, uigennemsigtig og 'uregerlig'. Derved lærer eleverne ikke blot at mestre teknologi men at leve og eksistere i en mere-end-menneskelig verden. Artiklen afsluttes med en ufærdig liste af forslag til, hvordan faget kan videreudvikles. Håbet er, at listen kan inspirere praktikere i folkeskolen til på den baggrund at udvikle egne idéer og læringsaktiviteter. 


\section{Technology Comprehension in a More-Than-Human World}

\section{Introduction}

Technology is on the agenda in the societal debate. We are currently engaging with the problem of technology and especially digital technologies and the increasing datafication of society that has occurred over the last decades to an extensive degree (Castells, 2003; Kitchin, 2014; O'Neil, 2016; Schäfer \& van Es, 2017). Concerns revolve around the power of the tech giants, the impact of internet and social media platforms, data and datafication, robotics, data breaches and theft, privacy and surveillance, threats to democracy and social coherence due to digitization, hacking and cybercrime, post-truth and fake news and so on. The consequences of IT and the problems that may follow from its pervasiveness and complexity are thus high on the societal agenda. In that respect, "Technology comprehension" proposed as a new course in the public schools of Denmark seems highly appropriate and timely. We - as citizens in general - must learn to engage with the role of information technology and be empowered to take part in the formation of our future societies. It has dawned on many of us, that it should not be up to the aptly named tech giants such as Facebook, Google, Amazon, Microsoft, etc. in combination with computer scientists and engineers to design and define our increasingly digitized reality. As Manual Castells stated 15 years ago, "Technology does not determine society - it is society" (Castells \& Cardoso, 2006, p. 3).

This being the case, not only raises the question: "how are digital technologies shaping our lives and society at large and how do we - as individuals and society - meet the challenges involved in this societal transformation?" It also raises the more fundamental question "what is technology and what characterizes our relation to technology?" In this article, I wish to unfold this question and relate it to the technology comprehension course, since how we think about and perceive technology is arguably consequential for how we practice and con- 
duct our lives and societies and accordingly, it is consequential for how we consider possibilities, problems, solutions and necessary actions. I will argue that we need to challenge a preferred and inherently humanistic and anthropocentric understanding of technology that sees technology as ideally a designed object and as subject to human control. This is an understanding that has dominated throughout enlightenment and modernity. However, my argument is that it is both inadequate and problematic because it keeps us in a frame of thinking that perpetually reproduces the idea of technological solutions to problems. Briefly put and based on the broad research field of science, technology and society (STS), the problem is that when we prefer to think of technology as an object designed by human beings, it easily follows that we consider the consequences of technology is due to or caused by the design and the intentions of the human creator(s) (Danholt \& Gad, 2021; Jasanoff, Markle, Peterson \& Pinch, 2001; Sismondo, 2009). This means that when we encounter technological problems, we may tend to see them as either the products of human intentions or as being due to inadequate or poor design and thus still, however in another respect, determined by human beings, only now due to human inability or fallacy. In both cases, what is reproduced is the idea that technology is determined by human actions either by design or use. And from that assumption follows that technology can be designed in better ways - and thus, that they ideally can become the objects that we wish for, namely objects that do neither more or less than what was intended by their human masters. However, as has been shown extensively in the field of science, technology and society studies (STS), technology is a transformative agent that adds to the world and comes with side-effects. It is in Donna Haraway's terms a trickster and accordingly, the above, and for many preferred and convenient, comprehension of technology as an object mastered by man, is flawed and simplistic (1991, 1997). Instead, as suggested in STS, technology is more adequately a transformative agent that produces emergent and unexpected consequences (Callon, 1989; Haraway, 1997; Latour, 1999; Law, 1991; MacKenzie \& Wajcman, 1999; Perrow, 2011; Winner, 1980). The field of STS has grown and existed for well over 40 years and dates further back to the work of among others, the philosophers Martin Heidegger and Gilbert Simondon (Heidegger, 1978; Simondon, 1980). The field provides a rich resource of empirical studies and theoretical concepts for acknowledging, analyzing and discussing the role of technologies for humans and societies (Danholt \& Gad, 2021; Farias, Roberts \& Blok, 2020, Jasanoff et al., 2001; Sismondo, 2009).

This comprehension of technology as a transformative agent is what I find crucially missing in the technology comprehension course in its current form. An understanding of technology as adding to and 
transforming reality and thus escaping human mastery, not by accident, but by default, is what we must learn to acknowledge and live with. Not an idealistic idea of technology that we chase and which will continue to disappoint us. This is also pertinent with respect to our current worldly condition in which climate changes make evident that we exist in a more-than-human world. We are not the masters of our existence or of the world. Ironically, humans acting as if we were the masters of the world, during the last 3-400 years (a very brief period of time considered on a planetary timescale), has led to a situation in which our actions seems to return to us with a vengeance, as the Belgian philosopher Isabelle Stengers has formulated it (2015). The planet, the climate, water, ice, animals and objects of various sorts have become agents that act upon us and must be taken into account in a manner that we have not anticipated. The world has become a forceful agent that cannot be negotiated with in the manner that we are used to negotiate among ourselves in our political arrangements, and as if we are the only ones on the planet capable of doing stuff (Latour, 1993, 2004a; Stengers, 2015). The current COVID-19 pandemic is a good example of this. We witness politicians, decision makers and the public negotiate and disagree on what should be done. In many cases, as if it was up to them and us as human beings to decide how COVID-19 will act, but the main character - COVID-19 - does not partake in these debates, nor does it care about them. It just goes about its 'business', spreading, mutating and so on. What we need to learn or perhaps more accurately re-learn (since for thousands of years we - the human beings - have indeed lived in a world where we were submitted to the brute forces of nature), is that although digital technologies and planetary forces are indeed not the same, they are both 'forces' we need to learn to think differently about, in order to develop our understanding, actions and ideas about our capacities and limitations and in turn be able to form 'liveable futures' (Haraway, 2016). The public school seems an obvious place to initiate and facilitate that movement.

The article is structured in the following manner. In the next part, I will briefly unfold central insights from science and technology studies, which I find missing in the current presentations of the technology comprehension course proposal, namely seeing and understanding technology as an unruly actor in a more-than-human world. Secondly, I will present and discuss the technology comprehension course. Thirdly, I will propose some brief suggestions for developing and teaching the course and lastly, I will conclude by summing up and making some final remarks. My overall point in the text is that perhaps we need to think of the school as a place in which exploration and articulation of uncertainty and incomprehensibility could pave a way for creating not future designers of technology, but resilient people who 
can live and act in an uncertain more-than-human world, in which we do not have a full understanding of technology (or other matters such as the climate), but still can act and make choices. As sociologist and organisation scholar Herbert Simon pointed out, information is always limited and rationality-bounded, also and especially when there seems to be an abundance of information, as we tend to think is the case today with the internet (1982). Not understanding how a given app or technological device functions, can be enough to guide decision making, for instance that one - for those reasons - chooses not to use it. I would argue that what is needed in an uncertain future is people who can challenge existing ways of living and expand and invent new ways of imagining and living in a more-than-human world. People that are able to find middle ground between "an apocalyptic no-hope scenario of the future" and a "no need to worry and act - science and technology will fix the world" scenario as suggested by Donna Haraway (2016).

\section{Technology as Actor - a More-than-Human Perspective}

In a classical text by the American political theorist and technology scholar Professor Langdon Winner entitled: "Do artifacts have politics?", Winner points out that we need to develop our understanding of technology (1980). On the one hand, we should be cautious to think that technology is simply a reification and implementation of human will and politics -what can be referred to as a form of social determinism: humans fully determine how technology is designed and with what consequences. On the other hand, Winner points out, we should also avoid the opposite understanding, namely that technology is completely detached from human actions and politics. A technological determinist understanding where technological development is understood as driven by its own internal logics detached from social and cultural factors. This version is often expressed in the form of the argument: "You cannot stop the technological development", as if technological development is not implicated by human actions such as power, politics, wealth, consumption, governance, law, etc. Winner's text is written in early 1980 and we still encounter these two equally simplistic and limited versions of technology in the public media, in political arguments, in common discourse, in sale speeches for new technologies, in expert arguments and so on. Winner offers, among others, an example of how politics and technology such as infrastructures is mutually implicated. The example provided is about 
something as trivial as low bridges built in New York in the 1930s. The bridges made it impossible for public transportation such as buses to pass underneath them and reach the beaches on Long Island in contrast to smaller private automobiles, which could pass. Therefore, the bridges effectively prevented the poor and mostly coloured parts of the New York population, who could not afford automobiles, to come to the beaches, whereas the richer and mostly white part of the population, with cars, had access. The example serves to show that something we tend to think of as a trivial infrastructural and non-political artifact (a bridge) can be highly political. It can act as a segregation device. More importantly, what a given technological artifact is or can be is indeed open and contingent. It depends on other things and circumstances. The specific technology can be many things and have many purposes and consequences which are not 'built into' the artifact, but materialize as it is introduced and developed in and through relations to other things and situations (Jensen, 2015). Accordingly, Winner's example has been debated and whether or not Robert Moses, the city planner of New York at the time, actually intended the bridges as race segregation devices or not, is - and continues to be - debatable. The point is that to fully decide once and for all whether or not the bridges were intended as race segregation devices misses the point about technology and its many-faced and contextual qualities. Because in that case, we are trying to do what Winner warns against, namely to pin down technology as simply human politics inscribed into an artifact or as a politically neutral artifact. The point is not whether the bridges were actually by human actor intended in a specific manner or not. The point is that the bridges clearly can function as race segregating devices under the given societal and demographic circumstances of 1930 s New York. To determine whether or not it is intended by its designers is to limit our comprehension of technology and reduce technology to an artifact that both in its design and use is determined by humans.

In continuation of Winner, another important figure of science and technology studies is the French sociologist and anthropologist Bruno Latour, who is also a central voice in current climate change debates. Latour opens one of his most renowned texts on technology by referring to the Greek myth of Daedalus (1994). In the myth, technology is anything but a neutral instrument of human will. Instead, technology plays the role as that which betrays and leads astray, it intervenes and changes the trajectory of the story and the will of the human actors in the story. Latour proposes that we need an understanding of technology as a transformative actor. Central to Latour's work, is the concept of translation. Latour defines it as follows: "I use translation to mean displacement, drift, invention, mediation, 
the creation of a link that did not exist before and that to some degree modifies two elements or agents" (1994, p. 32). As an example of translation, Latour juxtaposes the two positions expressed in the US gun legislation debate. On the one side, we have the anti-gun argument that says: "guns kill people!", which clearly locates the problem with technology (technology determinism) and on the opposite side, we have the pro-gun argument stating: "People kill people!", which holds that guns are not the problem, but those that use the guns. An example of social determinism. Latour sides with none of the two positions but offers an alternative: it is the coming together of gun and person that kills. In Latour's terms, the hybrid: gun-person. Obviously, the gun needs someone to pick it up and fire it, in order for it to kill or harm, but the point is also that the person becomes a much more lethal actor with the gun in hand. So, both gun and person need each other to carry out killing by gunshot. With guns accessible in society, human will and intentions are therefore being changed - they are translated. Our programs of action, as Latour calls them, are changed by guns: "You had wanted only to hurt but, with a gun now in hand, you want to kill" (1994, p. 32).

The example is illustrative of Latour's notion of translation, but should of course be taken only as illustrative. The point is not that all people with guns become killers - that would be to fall back into technological determinism. No, the point is just that we-human beings - as embodied and situated beings, are affected and changed by technologies and that those technologies become realized in specific ways due to the particular situations and practices in which they are a part. Technologies make a difference! They add to the world and change actions, intentions, will, perception, experience, etc. in numerous and more or less obvious ways. Being able to analyze and acknowledge this hybridity of the human-technology relation: that we are changed by technology and how we in return change technology in specific situations, I would argue, should be a central component of technological empowerment. Because being able to understand what we become with technology in specific situations, i.e. how our programs of action are being formed, not by us or by the technology, but by the human-technology nexus, is essential for becoming agents capable of reflecting and acting in our daily lives and society. Increasing our awareness of our hybridity is central to becoming someone in, at least partial, control of our agency. To acknowledge and analyze moments and processes of translation is to 'stay with the trouble' (Haraway, 2016) of technology and not fall prey to reducing our understanding of technology in either a social or a technological determinist manner.

Let me offer a brief example of how one could use Latour's translational understanding of technology in the public school in relation 
to digital bullying. To stay with the Latourian argument, when we encounter digital bullying, we might either begin to locate the problem with the human being bullying, and then we talk about manners, ethics and behaviour on social media: how we should address each other, how we keep a respectful tone, how we do not share sensible content and so on. Or we may locate the problem with social media platforms and blame them for making us insensitive and isolated, algorithmically enhancing hateful and radical remarks and so on. However, what is missing in both of these approaches is the translational aspect that sees digital bullying as a hybrid product. Latour's point would be that we become different actors on social media platforms. We are not ill-mannered and rude from the onset - we become a different actor, a human-social media hybrid. We are not physically confronted with those we bully as there is a 'convenient distance'. Our bullying has an unknown, but potentially large audience - we might become 'famous' (receiving many likes), our new primary motivation may, with social media in fact, not be to bully, but to befriend numerous other and become popular. Viewed as such, the social media platform is not just 'the media' on which I conduct my already ill-mannered behaviour. No, it transforms my agency and who I am as a person, keeping in mind that of course, I am not determined by the social media platform - I may indeed also be ill-mannered, but the platform adds to or enhances some 'qualities' and decreases others. If we approach digital bullying in this manner, bullying becomes a more complex, multifaceted and strange phenomenon. It becomes something that we can try to disentangle and analyze explicitly as a practice, but also in a speculative and explorative manner. Arguably, we might establish a more exploratory and investigatory dialogue and perhaps also less morally weighted dialogue with the students. We could explore how digital bullying is comprised and emerges in specific situations, what kind of feelings, motivations and experiences is involved and the processes that leads to certain bullying actions. Why and how bullying can happen 'unintendedly' and so on. And of course, through such an exploratory investigation, we could also ideally end up developing strategies and other forms of hybridity that prevent digital bullying.

The point is that Latour's translational and hybrid approach allows for picking apart and composing and constructing action and agency - instead of understanding it as a closed or determined matter given either by nature, sociality or what not. Digital bullying can thus become an exploration of how agency is configured and hybrids emerge and we can have a different dialogue, that is not from the outset configured as specific persons' or personalities' problem - or conveniently placed far away as something Facebook, Instagram and Twitter 'makes us do'. 
In the next part, I present the technology comprehension course based on the material that describes the competence areas of the course. I focus on how technology is perceived and presented in the material. What I will argue is that the description of the course repeats what can be said to be mainly humanist and modernist conceptions of technology, critical reflection and empowerment, which, based on STS, in some respect fails to meet the challenges presented to us today - not only in relation to technology, but also more broadly in relation to the formation of liveable futures and prevention of what design researcher Tony Fry and others have referred to as de-futuring (2020). The program is currently in a test phase that includes 46 schools in Denmark. Therefore, I focus on what is stated about the new course. I do not address or analyze concrete teaching practices, which of course would be very relevant, but lies beyond the scope of this article. First, I briefly account for the four core elements in the course and then, I discuss them based on what I have presented above as a more-than-human comprehension of technology, respectively a recognition of the agential qualities of technology presented in especially posthumanists parts of STS and exemplified in the works of Bruno Latour, Isabelle Stengers, Donna Haraway and Andy Pickering among others (Haraway, 1991, 2016; Latour, 1987, 1999; Pickering, 1995, 2011; Stengers, 2010, 2011).

\section{About the Course}

The course "technology comprehension" is proposed as a continuing course throughout the Danish public school education from the 1st to the 9 th grade -9 years in all. So, from entry level to graduation, the students will be taught the course. As mentioned, the course is currently in a test phase (2019-2021) and is thus presently not an independent course, but integrated in other courses such as Danish, Math, Science, Craft and Design.

The course is structured around 4 main competence areas: 1. Digital Empowerment, 2. Digital Design and Design processes, 3. Computational Thinking and 4. Technological capacity/ability to act technologically. My main focus in the following will be on the first, since it is the one that comes closest to include and describe an understanding of technology, which is why I will present the three others first and then close with discussing the first in more detail. 
Digital Design and Design Processes

Digital design and design processes focuses on the creative processes under which digital artifacts are constructed, including the choices and opt-outs that the designer has made in the process. Digital design and design processes deal with the planning and implementation of iterative design processes, taking into account future use contexts. Students must learn to frame complex problems in order to plan, implement and argue for the design of their own digital artifacts.

(Ministry of Children and Education, 202ob)

This area focuses on how to facilitate design processes, e.g. being able to manage a design process, learn to "frame complex problems in order to plan, implement and argue for the design of their own digital artifacts".

Computational Thinking

Computational thinking focuses on students' ability to model reality so that elements can be performed computationally. Computational thinking deals with the analysis, modelling and structuring of data and data processes which means students learn to decode phenomena and processes from everyday life, from academic contexts and in digital artifacts and describe these in the form of algorithms and digital models.

(Ministry of Children and Education, 2020a)

This competence focuses on learning computer science in a more accessible and pedagogical manner and basic system developments approaches such as object-oriented programming. The focus is on learning to model a real-life situation and translate it into a problem that can be "solved" or processed by software and computers.

Technological capacity/ability to act technologically Technological capacity/ability focuses on language, expressiveness and mastery of tools in relation to being able to express computational thoughts in a digital artifact. Technological capacity is about mastering computer systems, digital tools and associated languages as well as programming. Through the work with this area of competence, the students must learn to use many different digital technologies, just as they must learn strategies and gain experience in, for example, troubleshooting and solving problems in relation to these and being able to make the right decision about choosing tools.

(Ministry of Children and Education, 2020d) 
This follows in continuation from the two above, but emphasizes the competence to be able to assemble different technologies in order to configure devices for a given problem, including to being able to do problem solving and acquiring hands-on experience with IT.

Before we turn to Digital Empowerment, I will point out what I find significant with the three above in relation to a more-than-human comprehension of technology. Considered together, the three areas seem to promote that students learn to become competent designers and developers of technology. The focus is on how they become able to "frame complex problems in order to plan, implement and argue for the design of their own digital artifacts". Moreover, I gather that by means of computational thinking, the students learn to decode phenomena and processes from everyday life, from academic contexts and in digital artifacts and describe these in the form of algorithms and digital models. This statement seems to promote an understanding of real-world problems as available, translatable and solvable by computer models and algorithms. A point that is debatable to say the least. Not only might we, based on Latour, point out that nothing is ever easily translated without transformation from one setting to another, no phenomena are put into computer models without transformation.

Today, we see numerous examples of how algorithms and data models are biased and skewed in various ways (Bonde, Bossen \& Danholt, 2019; Danholt, Klausen \& Bossen, 2020; Edwards, 2013; Maguire, Langstrup, Danholt \& Gad, 2020; O'Neil, 2016). The intention of this competence area seems to be that the students as future computer model designers will be better equipped to avoid these mishaps, but still, it seems based on the idea that real-world problems can be modelled adequately and transformation be avoided. Translation is assumed to be what can be avoided through good analysis and design. Technology will ideally, and when well-designed, serve the purpose intended by the designer. But for Latour, translation is a condition of existence, not an anomaly that can be done away with. Lastly, as cited above: "Technological capacity is about mastering computer systems, digital tools and associated languages as well as programming" (Ministry of Children and Education, 2020d). Therefore, this competence follows in continuation of the two former ones with its emphasis on providing the students with computer science and design skills.

The main focus of the three competences above is to provide the students with skills related to becoming technology developers and designers. What remains unclear is whether and if so, exactly how those competences will enable the students to reflect on and raise critical questions regarding technology, such as, how it affects us as individuals and societies and whether they become able to formulate other types of solutions to other problems than technological ones. 
In short, how do these competences enable reflections and actions regarding what hybrids we are becoming? Rather, it seems that the three competences follow the STEM agenda which has been ongoing for the last 20 years which holds that what is needed are students who will become entrepreneurs and innovators of technology, so that we, in fierce global competition, can produce novel technologies and contribute to growth and increasing consumption of those technologies and allegedly save the globe and become richer all at once. So, based on these three competences, the course seems to me to add little but the same old STEM story: educating students to think that every problem has a technological solution. But this is where the fourth competence comes into the picture, which I will discuss further in the following. Will the competence area digital empowerment make the crucial difference and antidote to the aforementioned three?

\section{Digital empowerment \\ Digital empowerment deals with a critical, reflective and con- structive study and understanding of the possibilities and con- sequences of digital artifacts. In this competence area, the stu- dents acquire competences to assess the applicability, intentiona- lity and consequences of digital artifacts for the individual, com- munity and society. Based on academic assessment, students learn to come up with concrete suggestions for redesigning existing digital artifacts. \\ (Ministry of Children and Education, 2020c)}

First, we may note that this competence area emphasizes concepts I found lacking in the three former areas such as "critical" and "reflection". Further specified in this competence area, the students will learn the following:

— Technology analysis entails describing the physical and digital qualities of a digital artifact, including the shape, color, functionality, input technology and output technology of the artifact.

- Purpose analysis deals with analyzing the purpose, intention, intentionality and application of the digital artifact and they are determined via analysis of the artifact's use and specifications.

- Usage studies deal with the provision and analysis of empirical data that show how the digital artifact affects people and organizations in a specific usage practice.

- Impact assessment deals with reflection on the significance of digital artifacts for the individual, community and society, including ethical dilemmas associated with its use.

- Redesign deals with the design of an alternative solution based on the previous analyses and assessments. 
The first two of the above: based on Latour, technology analysis and purpose analysis can be described as non-black boxing technology and identifying the scripts built into technology (Akrich, 1992; Latour, 1994, 2000). Usage studies focus on the empirical analysis of the use of technology, or again following Akrich, how technologies are de-scribed in practice, i.e. how technology is actually used in practice. This is an important aspect since this is where the intentions 'built into' technology are translated which helps surface the unintended and agential aspects of technology. Impact assessment follows from the former and seeks to stimulate reflection on the consequences of specific technologies from the micro to the macro, as well as the ethical and political dilemmas. Lastly, redesign is about developing and proposing alternative solutions based on the previous steps. So, it seems that this area to some extent begins to engage with technology in an investigative, empirical and practical manner. However, as I will argue in the following it seems also to come with shortcomings and its own problems. In the following, I will discuss what characterizes digital technologies and relate it to the course, then secondly, I will discuss the role of critical reflection in this competence and lastly, the concept of empowerment.

\section{Technology as an Object or...?}

In the same text cited earlier, Latour notes another aspect of technology. Not only does technology transform programs of actions and thus our actions and capacities. The wonder of technology is also that when we begin analyzing and opening them up, we come to realize that they are composed of yet other parts and that they fold time and space:

99 Each of the parts inside the black box is a black box full of parts. If any part were to break, how many humans would immediately materialize around each? How far back in time, away in space, should we retrace our steps to follow all those silent entities that contribute peacefully to your reading this article at your desk? They have a peculiar ontological status... The depth of our ignorance about techniques is unfathomable. We are not able even to count their number, nor can we tell whether they exist as objects or as assemblies or as so many sequences of skilled actions....

(Latour, 1994, p. 37-38) 
Similarly, Haraway noted in her Cyborg manifesto thirty years ago, that many of our technologies are as sunbeams and they do not seem to have become more concrete or simple since then (1991). In fact, I would suggest that one of the primary qualities of those technologies that we use to a large degree today and which are also those that we discuss the most, such as Facebook, Google, TikTok, etc. seem not only to operate by, but rest upon being vast, complex, ambiguous, multiple, limitless and distributed networks. In short, they are anything but discrete and tangible. They are indeed nowhere and everywhere and want to meet our every need, while capitalizing, on what few, if any, of us are able to comprehend the value of, let alone, what transactions we are participating in.

So, for pedagogical reasons, as it is proposed in the digital empowerment competence, the students should learn to unpack technologies but following Latour and Haraway, the learning objective should perhaps not be that they come to a final conclusion and complete unpacking of the technologies. No, the important learning goal is that the students realize, that technologies do not unpack easily and that we do not end with the essential parts neatly and transparently laid out for us. The learning objective of the exercise is that layers of opacity are endlessly disclosed and new questions and concerns rather than answers are produced. The point is that during the process, the initial opacity has become a new type of opacity, which can be productive in generating new concerns, questions and ways to act. What I would caution against is a learning objective and pedagogy that claims to end up with a technological object as fully disclosed and transparent, because then we are back with the idea where technologies are designed objects that can be disassembled and their inscribed intentions discovered and listed.

The problem is if the teachers prefer "perfect" case-examples of technologies that end up reproducing a notion of technology as a circumscribed object. The challenge of the teacher is to be courageous enough to stay with the 'unfathomable' technologies and be able to facilitate a learning practice where the students come to appreciate the value of tracing and unpacking technologies, without coming to the bottom of the matter - a fully disclosed technological object. Instead, the students should learn to appreciate the development of their concerns, questions and ways of re-formulating and re-interpreting the technological object due to its unfathomable character. 


\section{Analysis and Critique as Vehicles for Design}

When we take into account the progression described in the Digital Empowerment competence area, it seems that the endpoint is design or re-design. Obviously, many critical reflections may be produced during the process, however, my concern is that when the goal of an analysis of technology is tied to the obligation to design another arguably better one, then the analysis may suffer and be limited due to this obligation. This caution is based on the work of the Belgian philosopher of science and technology, Isabelle Stengers (2000, 2017). Stengers is sceptical of the predominant knowledge economy that has pervaded research policies the last 30-40 years. In Denmark, it is mostly renowned by former minister of research Helge Sanders' expression: "from research to invoice" which states that research should result in economical revenue. Now, of course, it is not automatically a problem when research leads to innovation and profit. Indeed, research has played a substantial role for the development of contemporary society for good and bad. However, the problem is what happens to the practice of science and research, if and when it is expected to produce economic value? How does it affect what research is being proposed and carried out? What questions are asked and so on? Stengers argues that the knowledge economy is poison to research, not because research should be free from obligations. On the contrary, Stengers argues for science, which is thoroughly interested in the question of relevance, and for the idea that science and research should not reside in the ivory tower, but be intimately involved with society. The problem, according to Stengers, is that when relevance is limited to economic value and growth then we are faced with a poisonous environment for science, research and society in a broader sense.

With this in mind, the problem with the current progression of the course is that design plays the role as the endpoint. If that is the case, then what is to prevent the analysis from being determined or limited by the design's ambition? What prevents the students from preferring a shallow and quick analysis of the problem that points nicely to a probable design solution? Why should the students be interested in producing an analysis that exhibits complex, ambiguous 'wicked problems' filled with dilemmas, which characterizes the problems that we face in relation to digital technologies, climate changes, immigration and so on? Alas, complexity, ambiguity and more questions and problems are often what comes out of research processes - not clarity. So, on that note, the point from a more-than-human perspective is to either suspend design as the end goal of the process or considerably broadening the scope of what is to be designed. Perhaps, there could be a social, emotional, conceptual, aesthetic, orga- 
nisational, behavioral, etc. (or more likely a conglomerate of these) 'solution' to a given problem, not just a technological one. This would also be a way of including competences from other courses in the public school. What if the re-design of a technological problem or device should be in the form of a short story or a sporting activity?

Another point is how critique seems to be conceived in the description of the course. Critique is exercised on existing technologies: technologies are analyzed, unpacked and thereby rendered critiqued and on that basis, a novel technology is designed. Critique thus takes on a modernist and progressionist character, in which the present condition, present technologies are cast as objects that can be critiqued and improved upon. Modernity's perpetual machine is set in motion (Fry, Dilnot \& Stewart, 2015; Latour, 1993). The problem with this "machine" is that it reproduces a history of no history, i.e. a history that repeats the same narrative over and over again: state of the art technology or science rules, until the point where it fails somehow or its shortcomings are being exhibited and thereby, room is made for a new innovation or novelty and so the story goes on. However, in a more-than-human world, the point is that at every instance, there are multiple and interrelated problems and solutions. Problems and solutions are entwined and exceeds human capacities and mastery. They are intrinsic to existence, which in turn leaves us in another relation to them. Belief in continual progress and mastery of our condition become difficult to uphold and instead it becomes a matter of how we participate in a more-than-human ontology. So, the point in relation to critique is if we do not take it into consideration, it may easily become the basis of perpetual production and consumption of technology.

Furthermore, as Latour has pointed out, it seems that nowadays we have all become "experts" in critique and de-construction leading to a situation of mistrust in everything but one's own preferred truths (Latour, 2004,b). My point is that critique of technology or from 'my point of view' may become easy and cheap, if the basis of critique is not also closely reflected upon and challenged. Instead of critique, it might be better to consider what we care for, what do we want to keep, what is working and what do we not want to part with? In addition, existence is indeed a very critical actor that, in itself, produces situations with dilemmas, ambiguity, complexity, suffering, hard choices and no easy answers. Learning to think in terms of how to live and exist under those conditions seems highly relevant and something that the course might entail instead of contributing to the same old story of technical fixes to existing problems. This leads me to the last point related to empowerment. 


\section{Empowerment}

Empowerment is a contested concept and it is used in many mundane ways for better or worse. I will not offer a definition of empowerment but a way of thinking about empowerment in relation to technology that is different than the one I see in the course. As is explicitly stated in the course description, the notion of empowerment implies mastery of technological devices acquired through skills in designing and analyzing technology. Accordingly, the course rehearses a humantechnology relation in which humans ought to have control over technology. I also think it is fair to say, that a primary motivation behind the program is the understanding that we - ordinary people and children - have somehow lost mastery over technology and that this must be remedied by creating a future generation of digitally skilled people. Empowerment in the course description, I thus propose, means 'power-over' something - respectively technology.

However, let me offer an alternative notion of empowerment inspired by the feminist scholar and neopagan witch(!), Starhawk (1997). Starhawk presents a situation in which she and a friend are walking in the woods along a trail where other people have littered. Starhawk and her friend take it upon themselves to bring garbage bags on their walks and collect the trash. Not an example that immediately lends itself to ideas of empowerment, but what Starhawk proposes is that empowerment is something that we can acquire through our ability to transform how we relate to and think about a given situation. It is a 'power within'. In fact, this is Starhawk's definition of magic: our ability as human beings to willfully change how we think and relate to a given situation. Instead of feeling disgusted and diminished by cleaning up other people's trash and thereby placing oneself in an inferior position, what Starhawk and her friend do is that they think of their garbage collecting as not being forced upon them due to the recklessness of others, but as something they choose to do for the sake of the forest and the animals. Now, picking up trash becomes something that benefits the forest and thus something done as a matter of care, not something they do as a disgusting service for reckless people. Picking up other people's trash becomes an empowering event, because not only do Starhawk and her friend think of what they are doing as a matter of care, but in addition, they have transformed the meaning of their actions and willfully parted with the notion that their actions are determined by other's actions and recklessness.

Based on Starhawk, I would therefore propose a different way of thinking about empowerment than presumed in the course description, where we broaden our scope from power-over technology to realizing and promoting the 'power within'. To my understanding, 
this implies that we realize that the ways we think and conceptualize technology also holds great potentials for change and re-invention. We do not have to become designers of technology in order to be empowered. We may be empowered through ways of thinking differently about technology. Also, because becoming designers of technology may in fact mean that we reify and reproduce ideas about technology as designed objects and instruments of human will. Instead, I propose that by acknowledging the more-than-human quality of technology, we become better equipped to intervene in and reconfigure our relations with technology, because technology cannot be reduced to a designed object, but is by and large a relation comprised of multiple humans and non-humans.

\section{Suggestions for the Development of the Course}

Based on the argument and the analysis of the course throughout this text and what I have called a more-than-human perspective, I propose the following suggestions for the development and teaching of the course.

- Make it a central concern to discuss technology as a human-technology nexus.

- Promote and exercise a translational approach to analyze technological problems by (as briefly exemplified with the digital bullying example).

— Train the students in understanding their agency and themselves as hybrids and encourage them to think about other types of hybridity that can help solve a given problem or habit.

— Train the students' abilities to communicate and convey dilemmas, ambiguity and complexity. Experiment with 'the more complexity and detail, the better' formats.

— Train the students to design more-than-technological solutions to problems.

— Focus on what is that the students as a collective care for and want to promote - not on critique. 
- In relation to computational thinking, focus on what the approach leaves out and cannot take into account and how a given real-world problem is being transformed by the computational thinking process.

— Train the students in empowerment as a 'power-within' and the ability to think differently about things - not as 'power-over' something.

\section{Final Remarks}

The problem with the course is that the very ambition of empowering the students technologically may, ironically enough, entail that simplistic and idealist ideas about technology are reproduced through easy to teach examples. Making the students technologically savvy and giving them this experience may mean that we steer clear of the complexity, opacity and more-than-human qualities related to our technologically permeated life. How do we counterbalance the dominance of tech giants? By becoming like those that have made fortunes on designing technologies to serve their interests and who promote ideas about technology as designed objects, not actors that escape mastery? Or by becoming persons who do not reduce technologies to objects, but can see them as complex, distributed and opaque and as actors that create differences and a range of unintended consequences? I would argue for the latter, because by realizing technology as such entails a relational understanding of existence where the boundary between the self and others, inside and outside, is blurry and permeable. Thus, every problem becomes a simultaneous matter of reconfiguring relations and of changing not just things in the world such as technologies but also of changing oneself and one's ways of thinking and relating to things in the world. The 'playing field' is thus broadened. More points of intervention and transformation can be imagined and developed and one may simply become better at coming to terms with the fact that everything is not up to us - and in fact, that might serve a greater good and be beneficial for many other lifeforms on the globe because then, we might be less reckless as to how we go about treating those other lifeforms.

Based on this, we may start to tread a more realistic and liveable path that avoids two equally idealistic and basically mirroring versions of reality. One where we master our technological creations and one where we are determined by technology/technologies. Therefore, 
my point is that less may also in this respect be more. Those capable of understanding that technological existence unavoidably entails dilemmas, suffering, invisibilities, incomprehensiveness and always comes with a price may in the end be better off than a generation of technology designers who think they are capable of building the 'right' technologies. The former become designers of existence, not just technology, through their various ways of acting with and against technologies. On that note, I find that a course in technology comprehension in public schools that engages more-than-human perspectives have a crucial role to play in education.

\section{References}

Akrich, M. (1992). The De-Scription of Technical Objects. In W. Bijker \& J. Law (Eds.), Shaping Technology/Building Society: Studies in Sociotechnical Change (pp. 205-224). The MIT Press.

Bonde, M., Bossen, C., \& Danholt, P. (2019). Data-work and friction: Investigating the practices of repurposing healthcare data. Health Informatics Journal, 25(3), 558-566. https://doi.org/10.1177/14604582198564,62

Callon, M. (1989). Society in the Making: The Study of Technology as a Tool for Sociological Analysis. In W. E. Bijker, T. P. Hughes, \& T. Pinch (Eds.), The Social Construction of Technological Systems: New Directions in the Sociology and History of Technology (pp. 83-103). The MIT Press.

Castells, M. (2003). The Internet Galaxy: Reflections on the Internet, Business, and Society. Oxford University Press. DOI: 10.1093/acprof:oso/9780199255771.001.00o Castells, M. \& Cardoso, G. (Eds.). (2006). The Network Society: From Knowledge to Policy. Johns Hopkins Center for Transatlantic Relations.

Castells, M. \& Cardoso, G. (Eds.). (2006). The Network Society: From Knowledge to Policy. Johns Hopkins Center for Transatlantic Relations.

Danholt, P. \& Gad, C. (Eds.). (2021). Videnskab, teknologi og samfund: En introduktion til STS. Hans Reitzels Forlag.

Danholt, P., Klausen, M. B., \& Bossen, C. (2020). Data: A Cosmopolitical Approach. STS Encounters, 11(1), 255-280.

Edwards, P. N. (2013). A Vast Machine: Computer Models, Climate Data, and the Politics of Global Warming. The MIT Press.

Farias, I., Roberts, C., \& Blok, A. (Eds.). (2020). The Routledge Companion to Actor-Network Theory. Routledge.

Fry, T. (2020). Defuturing: An Introduction to a New Design Philosophy. Bloomsbury Publishing.

Fry, T., Dilnot, C., \& Stewart, S. C. (Eds.). (2015). Design and the Question of History. Bloomsbury Publishing.

Haraway, D. J. (1991). Simians, Cyborgs, and Women: The Reinvention of Nature. Routledge. 
Haraway, D. J. (1997).Modest_Witness@Second_Millennium.FemaleMan_Meets_On coMouse: Feminism and Technoscience. Routledge.

Haraway, D. J. (2016). Staying with the Trouble: Making Kin in the Chthulucene. Duke University Press.

Heidegger, M. (1978). Being and Time. Wiley-Blackwell.

Jasanoff, S., Markle, G. E., Peterson, J. C., \& Pinch, T. J. (Eds.). (2001). Handbook of Science and Technology Studies. Sage Publications, Inc.

Jensen, C. B. (2015). Experimenting with political materials: environmental infrastructures and ontological transformations. Distinktion: Journal of Social Theory, 16(1), 17-30. https://doi.org/10.1080/16oog10X.2015.1019533

Kitchin, R. (2014). The Data Revolution: Big Data, Open Data, Data Infrastructures \& Their Consequences. SAGE Publications.

Latour, B. (1987). Science in Action: How to Follow Scientists and Engineers through Society. Harvard University Press.

Latour, B. (1993). We Have Never Been Modern. Harvard University Press.

Latour, B. (1994). On Technical Mediation-Philosophy, Sociology, Genealogy. Common Knowledge, 3(2), 29-64.

Latour, B. (1999). Pandora's Hope: Essays on the Reality of Science Studies. Harvard University Press.

Latour, B. (2000). The Berlin Key or How to do Words with Things. In P. Graves-Brown (Ed.), Matter, Materiality, and Modern Culture (pp. 10-21). Routledge.

Latour, B. (2004a). Politics of Nature: How to Bring the Sciences into Democracy. Harvard University Press.

Latour, B. (2004b). Why Has Critique Run out of Steam? From Matters of Fact to Matters of Concern. Critical Inquiry, 3o(2), 225-248.

Law, J. (1991). A Sociology of Monsters: Essays on Power, Technology, and Domination. Routledge.

MacKenzie, D. \& Wajcman, J. (1999). The Social Shaping of Technology. Open University Press.

Maguire, J., Langstrup, H., Danholt, P., \& Gad, C. (2020). Engaging the Data Moment: An Introduction. STS Encounters, 11(1), 7-26.

Ministry of Children and Education. (2020a). Computationel tankegang. Located [18.09.2021] at: https://emu.dk/grundskole/teknologiforstaelse/ computationel-tankegang

Ministry of Children and Education. (2020b). Digital design og designprocesser. Located [18.09.2021] at: https://emu.dk/grundskole/teknologiforstaelse/ digital-design-og-designprocesser

Ministry of Children and Education. (2020c). Digital myndiggørelse. Located [18.09.2021] at: https://emu.dk/grundskole/teknologiforstaelse/digitalmyndiggorelse

Ministry of Children and Education. (2020d). Teknologisk handleevne. Located [18.09.2021] at: https://emu.dk/grundskole/teknologiforstaaelse/ teknologisk-handleevne

O’Neil, C. (2016). Weapons of Math Destruction: How Big Data Increases Inequality and Threatens Democracy. Crown.

Perrow, C. (2011). Normal Accidents: Living with High Risk Technologies. Princeton University Press. 
Pickering, A. (1995). The Mangle of Practice: Time, Agency, and Science. University of Chicago Press.

Pickering, A. (2011). The Cybernetic Brain: Sketches of Another Future. University Of Chicago Press.

Schäfer, M. T. \& van Es, K. (Eds.). (2017). The Datafied Society: Studying Culture through Data. Amsterdam University Press.

Simon, H. A. (1982). Models of Bounded Rationality. The MIT Press.

Simondon, G. (1980). On the Mode of Existence of Technical Objects. University of Western Ontario.

Sismondo, S. (2009). An Introduction to Science and Technology Studies. WileyBlackwell.

Starhawk. (1997). Dreaming the Dark: Magic, Sex, and Politics. Beacon Press.

Stengers, I. (2000). The Invention of Modern Science. University of Minnesota Press.

Stengers, I. (2010). Cosmopolitics I. University of Minnesota Press.

Stengers, I. (2011). Cosmopolitics II. University of Minnesota Press.

Stengers, I. (2015). In Catastrophic Times: Resisting the Coming Barbarism. Open Humanities Press. DOI: 10.14619/016

Stengers, I. (2017). Another Science is Possible: A Manifesto for Slow Science. Polity. Winner, L. (1980). Do Artifacts Have Politics? Daedalus, 109(1), 121-136. 